\title{
PENGARUH CORPORATE GOVERNANCE TERHADAP FIRM'S DEBT PADA PERUSAHAAN SEKTOR INDUSTRI BARANG KONSUMSI PERIODE 2013-2018
}

\author{
Francisca $^{1^{\star}}$, Mariana Ing Malelak ${ }^{2}$ \\ 1,2 Program Finance \& Investment, Program Studi Manajemen \\ Fakultas Bisnis dan Ekonomi, Universitas Kristen Petra \\ Jl. Siwalankerto 121-131, Surabaya 60236 \\ E-mail: ${ }^{1} \mathrm{~m} 37416004 @ j o h n . p e t r a . a c . i d ;{ }^{2}$ mariana.ing@petra.ac.id \\ ${ }^{*}$ Penulis korespondensi
}

\begin{abstract}
ABSTRAK
Era globalisasi menjadikan perusahaan menjadi bersaing dan menentukan strategi bisnis yang sesuai dengan kondisi perusahaan. Kemampuan perusahaan dalam menentukan kinerjanya akan meningkatkan daya saing perusahaan. Penelitian ini bertujuan untuk meneliti pengaruh corporate governance terhadap firm's debt pada perusahaan sektor industri barang konsumsi periode 2013-2018. Sampel yang digunakan adalah 31 perusahaan sektor industri barang konsumsi yang tercatat selama periode 2013-2018. Metode analisa data dilakukan dengan menggunakan regresi data panel dengan fixed effect model dan random effect model. Variabel kontrol yang digunakan pada penelitian ini terdiri dari profitability dan firm size. Hasil penelitian in menunjukkan bahwa board size dan board composition berpengaruh signifikan terhadap short term debt, board size tidak berpengaruh signifikan terhadap long term debt namun board composition berpengaruh signifikan terhadap long term debt, serta board size dan board composition tidak berpengaruh signifikan terhadap total debt.
\end{abstract}

Kata kunci: Board composition, board size, corporate governance, firm's debt, firm size, profitability, teori keagenan.

\section{ABSTRACT}

The era of globalization makes companies competitive and determines business strategies according to company conditions. The company's ability to determine its performance will increase the company's competitiveness. This study aims to examine the effect of corporate governance on firm's debt in the consumer goods industry sector companies for the period 2013-2018. The sample used is 31 companies in the consumer goods industry sector recorded during the 2013-2018 period. The method of data analysis was performed using panel data regression with a fixed effect model and a random effect model. The control variables used in this study consist of profitability and firm size. The results of this study indicate that board size and board composition have a significant effect on short term debt, board size has no significant effect on long term debt but board composition has a significant effect on long term debt, and board size and board composition have no significant effect on total debt.

Keywords: Board composition, board size, corporate governance, firm's debt, firm size, profitability, agency theory.

\section{PENDAHULUAN}

Pada era globalisasi ini, perkembangan bisnis yang sangat pesat dapat menimbulkan persaingan dalam dunia bisnis. Persaingan dalam bisnis memicu perusahaan untuk menyusun strategi yang tepat sehingga kinerja perusahaan dapat meningkat. Hal ini berkaitan dengan konsep kualitas tata 
kelola perusahaan. Semakin tinggi kualitas tata kelola perusahaan, maka kinerja perusahaan akan meningkat.

Penerapan tata kelola perusahaan yang baik memiliki beberapa tujuan yaitu untuk mengurangi terjadinya konflik kepentingan, memastikan bahwa aset perusahaan digunakan secara efisien dan produktif, meningkatkan daya saing perusahaan secara nasional dan internasional serta mengoptimalkan nilai perusahaan dengan memperhatikan kepentingan terbaik bagi investor dan stakeholder lainnya (KNKG, 2006). Hal ini menunjukkan bahwa penerapan tata kelola yang baik tidak terlepas dari adanya perbedaan kepentingan antara shareholder dan manajer yang disebut dengan agency conflict. Untuk meminimalisasi agency conflict salah satunya dengan cara penggunaan sumber dana eksternal berupa hutang perusahaan, karena dengan penggunaan hutang yang besar akan mendorong manajer untuk lebih mendisiplinkan diri dalam pengelolaan keuangan perusahaan. Namun dalam penggunaan sumber dana eksternal berupa hutang, perusahaan juga harus mempertimbangkan keputusan permodalan yang efisien dan efektif bagi perusahaan. Hal ini sangat penting untuk diperhatikan karena kesalahan dalam menentukan struktur modal dapat meningkatkan risiko finansial seperti beban yang semakin besar, tidak dapat membayar beban bunga dan angsuran hutang.

Pada saat ini, banyak perusahaan dari berbagai sektor telah menerapkan prinsip Good Corporate Governance (GCG), salah satunya perusahaan pada sektor industri barang konsumsi. Adanya penerapan prinsip GCG pada perusahaan sektor ini dapat dipengaruhi oleh beberapa hal seperti susunan dalam dewan direksi, kebijakan dewan direksi dan sistem operating procedure (SOP) yang ada pada perusahaan. Hal tersebut dapat memberikan pengaruh bagi perusahaan dalam menggunakan pendanaan hutang. Untuk mengetahui penggunaan hutang pada perusahaan sektor industri barang konsumsi, berikut adalah grafik debt to asset ratio (DAR) pada perusahaan di sektor industri barang konsumsi tahun 2013-2018.

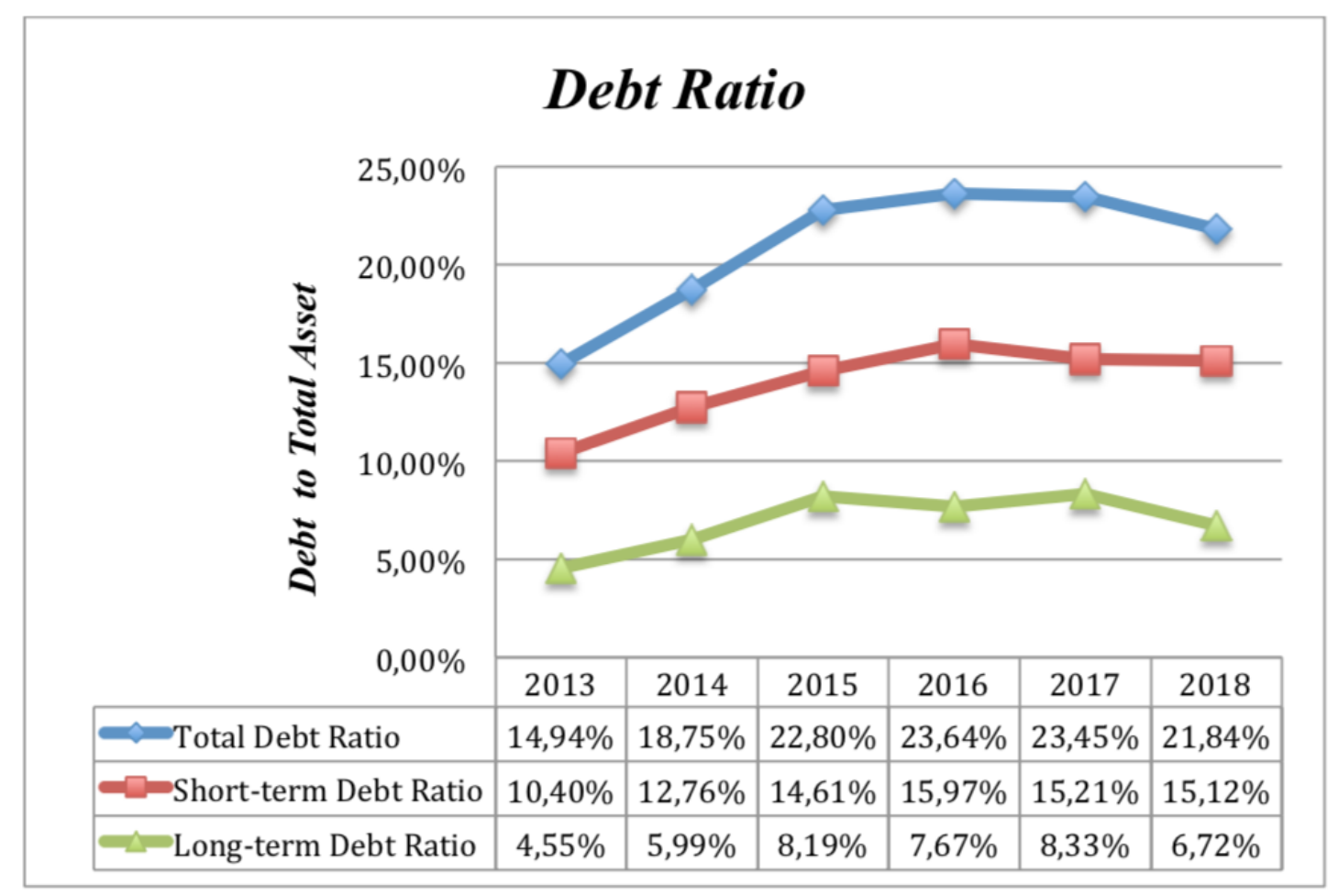

Gambar 1. DAR Perusahaan Sektor Industri Barang Konsumsi tahun 2013-2018 
Berdasarkan grafik di atas, pergerakan total debt, short-term debt, dan long-term debt secara keseluruhan mengalami peningkatan dari tahun 2013 hingga 2018. Namun, penggunaan dana hutang yang tinggi tidak menjamin adanya pertumbuhan net income perusahaan pada sektor industri barang konsumsi. Untuk mengetahui pertumbuhan net income, berikut adalah grafik pertumbuhan net income (NI) pada perusahaan sektor industri barang konsumsi tahun 2013-2018.

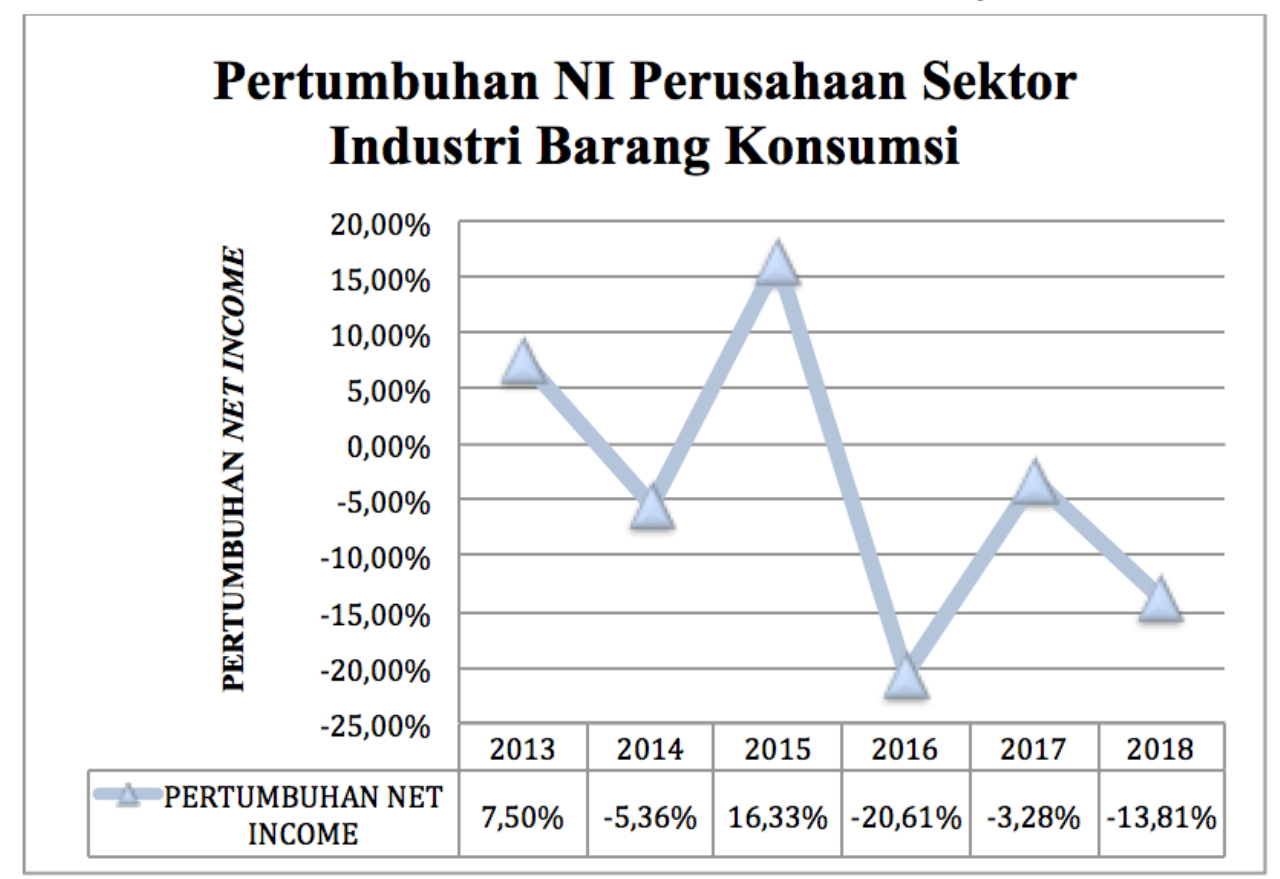

Gambar 2. Pertumbuhan NI Perusahaan Sektor Industri Barang Konsumsi tahun 2013-2018

Dapat dilihat dari grafik tersebut, pertumbuhan net income pada perusahaan sektor industri barang konsumsi mengalami penurunan yang sangat signifikan pada tahun 2016. Apabila membandingkan rata-rata pertumbuhan net income dengan penggunaan hutang pada tahun 2016, hal ini bertolak belakang dengan meningkatnya jumlah hutang perusahaan di sektor industri barang konsumsi. Selain itu, selama periode 2013-2018 juga terdapat tren yang dapat menjelaskan hubungan antara grafik hutang dan net income. Hal ini ditunjukkan dari grafik pertumbuhan net income yang cenderung mengalami penurunan pada tahun 2014, 2016, dan 2018 namun mengalami peningkatan pada tahun 2013, 2015, dan 2017.

Dengan melihat grafik hutang dan net income, dapat disimpulkan bahwa perusahaan dengan net income yang besar pada umumnya cenderung memiliki retained earning yang besar. Retained earning perusahaan yang besar dapat mempengaruhi peningkatan pada posisi equity perusahaan. Apabila perusahaan memiliki posisi equity yang besar, maka penggunaan hutang perusahaan akan menjadi minimal. Namun sebaliknya, perusahaan yang sedang mengalami kerugian akan cenderung memiliki retained earning dan posisi equity yang kecil. Hal ini disebabkan oleh penurunan net income yang dipengaruhi oleh pendapatan perusahaan yang tetap dengan biaya perusahaan yang tinggi atau pendapatan perusahaan yang menurun dengan biaya perusahaan tetap. Oleh karena itu, perusahaan akan membutuhkan hutang yang besar agar kegiatan operasional dapat berjalan dengan lancar. Melihat dari kondisi kedua grafik tersebut, hal ini dapat dipengaruhi oleh beberapa faktor internal perusahaan yang salah satunya adalah praktik GCG.

Dalam penerapan praktik GCG, terdapat perusahaan pada sektor industri barang konsumsi yang 
telah meraih penghargaan Indonesia Most Trusted Companies (IMTC) dimana penghargaan ini mengacu pada tingkat kepercayaan perusahaan yang dinilai oleh IICG (The Indonesian Institute for Corporate Governance). Salah satu perusahaan tersebut yaitu PT Unilever Indonesia Tbk. Pada tahun 2015, perusahaan ini telah meraih IMTC 2015 dari Majalah SWA dan IICG (Indonesia Institute for Corporate Governance). Selain itu, pada tahun 2018 PT Unilever Indonesia juga masuk dalam sepuluh besar perusahaan publik Big Cap di Indonesia dengan tata kelola perusahaan terbaik dan mendapat penghargaan sebagai entitas sektor non-keuangan terbaik pada ASEAN Corporate Governance Scorecard. Penghargaan eksternal yang menunjukkan tentang kualitas tata kelola perusahaan ini terus diraih oleh PT Unilever Indonesia Tbk dalam 5 tahun terakhir.

Apabila dikaitkan dengan hutang perusahaan, peneliti menemukan bahwa penjualan perusahaan dan rasio penggunaan hutang perusahan pada tahun 2013 hingga 2017 mengalami peningkatan. Hutang perusahaan yang meningkat disebabkan oleh kontribusi peningkatan pinjaman bank secara berkala dari tahun 2013 hingga 2017. Dengan adanya peningkatan pinjaman bank, maka terjadi peningkatan pada bunga hutang dan operating expense perusahaan. Secara tidak langsung, hal ini juga mempengaruhi penurunan pada operating income perusahaan yang disebabkan oleh kebijakan dewan direksi untuk mempertahankan posisi equity di angka yang tetap sehingga perusahaan menggunakan pendanaan hutang. Kebijakan dewan direksi tersebut dinyatakan dalam laporan direksi PT Unilever Indonesia Tbk pada tahun 2015 bahwa perusahaan memiliki fleksibilitas lebih tinggi dalam pembiayaan di masa depan dan memperkuat arus kas jangka pendek tanpa memegang uang tunai dalam jumlah besar terlebih dahulu karena perusahaan memiliki perputaran omset tinggi, modal kerja negatif serta siklus konversi kas dapat menguntungkan untuk efisiensi operasional. Dengan demikian, dapat disimpulkan bahwa keputusan pendanaan hutang pada perusahaan dipengaruhi oleh kebijakan dewan direksi yang memfokuskan pendanaan perusahaan pada kas jangka pendek. Kebijakan dewan direksi tersebut dapat dilihat dari variabel board size dan board composition yang termasuk dalam komponen dari praktik good corporate governance pada penelitian ini.

Pemilihan sektor industri barang konsumsi pada penelitian ini dilatarbelakangi oleh karakteristik perusahaan yaitu padat modal dan memiliki kebutuhan barang modal yang tinggi terutama pada aset lancar. Hal ini dikarenakan perusahaan pada sektor industri barang konsumsi merupakan bagian dari perusahaan sektor manufaktur yang juga padat modal. Secara umum, perusahaan pada sektor industri barang konsumsi akan cenderung menggunakan hutang jangka pendek untuk membiayai aset lancar dan hutang jangka panjang untuk membiayai aset tetap. Apabila dilihat dari gambar 1 , penggunaan hutang yang tinggi pada sektor ini disebabkan oleh penggunaan hutang jangka pendek yang lebih besar daripada hutang jangka panjang. Hutang jangka pendek yang besar disebabkan oleh perusahaan yang memiliki kekurangan dana laba ditahan untuk membiayai tingginya kebutuhan aset lancar sehingga perusahaan akan menggunakan pendanaan hutang.

\section{TEORI PENUNJANG}

\section{Corporate Governance}

Corporate governance didefinisikan sebagai suatu sistem yang mengatur dan mengendalikan perusahaan (Kurniati, 2019). Perusahaan- perusahaan yang memiliki tata kelola yang baik dapat membawa risiko keuangan dan non-keuangan yang lebih rendah serta menghasilkan shareholder return yang lebih tinggi. Hal ini dikarenakan sistem corporate governance yang baik akan 
memberikan perlindungan yang efektif kepada para pemegang saham (shareholder), tetapi juga akan melindungi pihak kreditur. Hal ini menyebabkan perusahaan akan memiliki akses yang lebih baik terhadap pembiayaan eksternal dan mengurangi systematic risk yang merupakan akibat dari krisis perusahaan dan skandal keuangan.

\section{1) Agency Theory}

Agency theory digunakan untuk memahami hubungan antara manajer dan pemegang saham. Manajer mewakili pemegang saham dalam transaksi bisnis tertentu dan diharapkan mewakili kepentingan terbaik pemegang saham tanpa memperhatikan kepentingan pribadi. Kepentingan yang berbeda dari para pemegang saham dan manajer dapat menjadi sumber konflik, karena beberapa manajer mungkin tidak bertindak secara sempurna dalam kepentingan utama para pemegang saham (Clarke and Gholamshahi, 2016). Miskomunikasi dan perselisihan yang dihasilkan dapat mengakibatkan berbagai masalah dalam perusahaan. Keinginan yang tidak sesuai dapat menimbulkan konflik antara masing-masing pemangku kepentingan dan menyebabkan inefisiensi dan kerugian keuangan.

2) Board Size

Board size merupakan determinan yang penting untuk menentukan efektifitas corporate governance sebuah perusahaan (Jackling \& Johl, 2009). Pada penelitian ini, board size menjelaskan jumlah anggota direksi dalam suatu perusahaan. Dewan direksi merupakan pihak yang bertanggung jawab dalam pembuatan keputusan tentang melakukan pengarahan, pengendalian, dan pengawasan atas pengelolaan sumber daya agar sesuai dan sejalan dengan tujuan perusahaan Selain itu, dewan direksi juga bertanggung jawab dalam mengupayakan tercapainya target-target perusahaan dalam segala aspek terutama aspek finansial perusahaan (Kusi et al., 2018). Dalam menjalankan tugasnya, dewan direksi harus bekerja secara optimal untuk meningkatkan nilai perusahaan yang dapat dilihat dari meningkatnya harga saham perusahaan.

\section{3) Board Composition}

Board of directors umumnya dibagi menjadi dua, yaitu inside directors / executive directors dan outside directors / independent non-executive directors (Adams, Hermalin, \& Weisbach, 2010). Inside directors atau executive directors merupakan direksi eksekutif dalam suatu perusahaan yang bertugas memberikan bimbingan melalui saran, nasihat, pengarahan, bantuan, yang berkenaan dengan pengurusan pengelolaan suatu perusahaan dan meningkatkan kinerja perusahaan yang bekerja secara full time di perusahaan (Adams, Hermalin, \& Weisbach, 2010). Sedangkan outside directors atau independent non-executive directors merupakan orang-orang yang tidak diperkerjakan secara langsung di perusahaan dan tidak memiliki ketergantungan psikologi maupun ekonomi pada manajemen perusahaan dan merupakan direksi yang tidak bekerja secara full time (Baysinger \& Butler, 1985).

\section{Capital Structure}

Struktur modal terdiri dari dua macam yaitu pendanaan internal (equity capital) dan pendanaan eksternal (debt capital) dimana pendanaan internal dapat diperoleh dari modal pribadi atau kelompok, sedangkan pendanaan eksternal dapat diperoleh melalui pinjaman yang diberikan salah satunya oleh bank (Ogier, Rugman, \& Spicer, 2013). Pada umumnya, dana internal suatu perusahaan dapat dilihat dari jumlah dana retained earning yang merupakan penyisihan laba perusahaan yang tidak dibagikan kepada pemegang saham. Sedangkan dana eksternal dapat dilihat dari jumlah hutang perusahaan atau penerbitan saham baru perusahaan. 
1) Firm's Debt

Menurut (Munawir, 2004) hutang adalah semua kewajiban keuangan perusahaan kepada pihak lain yang belum terpenuhi, dimana hutang ini merupakan sumber dana atau modal perusahaan yang berasal dari kreditur. Pendanaan hutang sering terjadi melalui pinjaman atau melalui penerbitan efek seperti obligasi. Periode pinjaman hutang ini bervariasi tergantung pada keinginan perusahaan dan krediturnya. Dalam pemilihan periode pinjaman, manajer harus mempertimbangkan besarnya biaya tetap yang muncul dari hutang berupa bunga yang akan menyebabkan semakin meningkatnya leverage keuangan dan semakin tidak pastinya tingkat pengembalian bagi para pemegang saham.

2) Pecking Order Theory

Teori ini menjelaskan tentang urutan pendanaan yang dapat digunakan oleh perusahaan, yaitu pertama perusahaan akan menggunakan sumber dana internal berupa laba ditahan. Apabila tidak mencukupi, perusahaan akan menggunakan dana eksternal berupa hutang, dan apabila masih tidak mencukupi, maka yang terakhir dilakukan adalah menerbitkan saham baru (Malelak, 2017). Menerbitkan saham baru dipilih sebagai opsi terakhir karena biaya yang dikeluarkan untuk menerbitkan saham baru lebih besar dibandingkan dengan laba ditahan dan hutang.

\section{Hubungan Antar Konsep}

Board size yang lebih besar akan dibutuhkan pemantauan yang lebih oleh pemegang saham kepada manajemen agar dapat mendukung kinerja manajemen perusahaan yang lebih efektif. Apabila board size semakin besar, maka pemantauan kepada manajer akan lebih sulit dan menjadi kurang efisien. Untuk memonitor aktivitas manajer dengan lebih baik, pemegang saham menggunakan hutang untuk meminimalisasikan agency problem dengan harapan manajemen dapat memaksimalkan kinerja perusahaan. Hal ini sesuai dengan penelitian (Abor, 2007) yang menyatakan bahwa board size berpengaruh signifikan terhadap firm's debt karena perusahaan dengan ukuran dewan yang besar dapat memberikan tekanan yang tinggi kepada manajer melalui pemantauan kebijakan yang ketat untuk melunasi kewajiban hutang sehingga nilai perusahaan dapat meningkat. Namun, hal ini tidak sejalan dengan penelitian Bulan \& Yuyetta, 2014) yang menyatakan bahwa board size tidak berpengaruh signifikan terhadap firm's debt karena ukuran direksi yang besar hanya menggambarkan jumlah anggota, tetapi tidak mencerminkan kinerja direksi yang aktif berpartisipasi dalam pengambilan keputusan-keputusan strategis perusahaan.

Perusahaan yang memiliki direktur independen yang tinggi cenderung untuk meminimalkan penggunaan firm's debt. Hal ini dikarenakan, direktur independen merupakan orang-orang yang tidak diperkerjakan secara langsung di perusahaan dan tidak memiliki kepentingan tertentu terhadap perusahaan sehingga direktur independen cenderung untuk bekerja dengan memaksimalkan potensi yang ada di perusahaan. Dengan memaksimalkan potensi yang ada di perusahaan, maka tingkat laba bersih perusahaan dapat bertambah sehingga penggunaan hutang dapat diminimalkan oleh perusahaan, karena perusahaan akan cenderung menggunakan sumber dana internal sebelum memilih pendanaan sumber eksternal pada saat melakukan pemilihan pendanaan. Menurut hasil penelitian (Wen, Rwegasira, \& Bilderbeek, 2002), board composition berpengaruh signifikan negatif terhadap firm's debt karena dengan adanya direktur independen, dewan direksi perusahaan cenderung untuk menekan hutang perusahaan karena mereka berfokus untuk meningkatkan harga saham perusahaan. Namun, hal ini tidak sependapat dengan penelitian (Sheikh \& Wang, 2012) yang menyatakan bahwa board composition berpengaruh signifikan 
terhadap firm's debt karena direktur independen dapat membantu shareholder dalam melakukan pemantauan kinerja dewan direksi lebih efektif dalam memaksimalkan kekayaan pemegang saham dengan adanya hutang yang tinggi.

\section{Kerangka Berpikir}

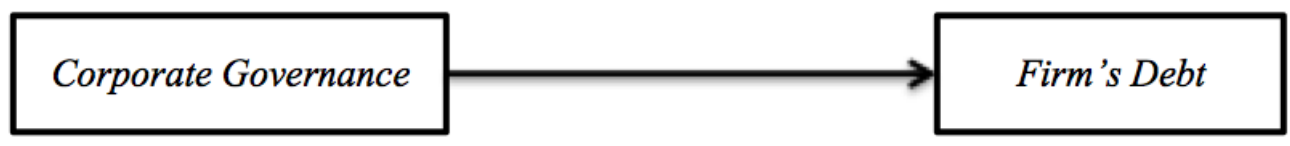

Gambar 3. Kerangka Berpikir

\section{Hipotesis Penelitian}

Hipotesis untuk penelitian ini adalah:

H1: Corporate governance (board size) berpengaruh signifikan terhadap firm's debt pada perusahaan sektor industri barang konsumsi periode 2013-2018.

H2: Corporate governance (board composition) berpengaruh signifikan terhadap firm's debt pada perusahaan sektor industri barang konsumsi periode 2013-2018.

\section{METODOLOGI PENELITIAN}

Penelitian ini menggunakan penelitian kuantitatif dengan metode asosiatif. Populasi pada penelitian ini yaitu perusahaan sektor manufaktur pada tahun 2013-2018 dengan sampel perusahaan terbuka sektor industri barang konsumsi pada tahun 2013-2018. Sampel penelitian diambil menggunakan teknik purposive sampling dengan kriteria sebagai berikut:

1. Terdaftar di Bursa Efek Indonesia (BEI) mulai dari tahun 2013-2018.

2. Memiliki data laporan keuangan dan laporan tahunan yang lengkap selama tahun 2013-2018.

3. Memiliki laporan tahunan yang di dalamnya terdapat laporan Good Corporate Governance (GCG).

\section{Definisi Operasional Variabel}

Definisi operasional variabel yang digunakan pada penelitian ini adalah sebagai berikut:

1. Firm's Debt, menggunakan 3 indikator empirik yaitu:

a. Short term debt:

Short Term Debt / Total Asset

b. Long term debt:

Long Term Debt / Total Asset

c. Total debt:

Total Debt / Total Asset

2. Board Size, menggunakan proksi Laporan GCG bagian susunan Board of Directors.

3. Board Composition, menggunakan indikator empirik: Jumlah direktur independen / Total dewan direksi

4. Profitability, menggunakan indikator empirik:

ROA : Earning Before Interest and Tax/Total Asset

5. Firm Size, menggunakan proksi Net Total Asset. 


\section{Teknik Analisa Data}

Pada penelitian ini, pengolahan data dilakukan dengan menggunakan program E-Views 11 untuk mengolah data secara statistik. Untuk menyelesaikan permasalahan di atas, langkah penelitian yang dapat dilakukan adalah sebagai berikut:

1. Mengumpulkan data serta melakukan perhitungan indikator empirik dari masing-masing variabel dependen, variabel independen, dan variabel kontrol

2. Menghitung rata-rata, standar deviasi, nilai maksimum, dan nilai minimal dari data yang digunakan (data deskriptif).

3. Menyusun persamaan regresi linear.

Persamaan regresi pada penelitian ini ada 2 model persamaan yaitu :

a. Persamaan tanpa variabel kontrol

$$
\begin{aligned}
& F D 1_{i t}=\alpha_{i t}+\beta_{1 i t}(B S)_{i t}+\beta_{2 i t}(B C)_{i t}+e_{i t} \\
& F D 2_{i t}=\alpha_{i t}+\beta_{1 i t}(B S)_{i t}+\beta_{2 i t}(B C)_{i t}+e_{i t} \\
& F D 3_{i t}=\alpha i t+\beta_{1 i t}(B S)_{i t}+\beta_{2 i t}(B C)_{i t}+e_{i t}
\end{aligned}
$$

b. Persamaan dengan variabel kontrol

$$
\begin{aligned}
& F D 1_{i t}=\alpha_{i t}+\beta_{1 i t}(B S)_{i t}+\beta_{2 i t}(B C)_{i t}+\beta_{3 i t}\left(\text { Profit }_{i t}+\beta_{4 i t}(\text { Size })_{i t}+e_{i t}\right. \\
& F D 2_{i t}=\alpha_{i t}+\beta_{1 i t}(B S)_{i t}+\beta_{2 i t}(B C)_{i t}+\beta_{3 i t}\left(\text { Profit }_{i t}+\beta_{4 i t}(\text { Size })_{i t}+e_{i t}\right. \\
& F D 3_{i t}=\alpha_{i t}+\beta_{1 i t}(B S)_{i t}+\beta_{2 i t}(B C)_{i t}+\beta_{3 i t}\left(\text { Profit }_{i t}+\beta_{4 i t}(\text { Size })_{i t}+e_{i t}\right. \\
& \text { dimana: }
\end{aligned}
$$

FD1 = Firm's Debt (short term debt); FD2 = Firm's Debt (long term debt); FD3 = Firm's Debt (total debt); $\beta_{1-4}=$ Koefisien Regresi; BS = Board Size; BC = Board Composition; Profit = Profitability; Size = Firm Size;

$\mathrm{e}=$ error term

4. Melakukan estimasi pemilihan model regresi data panel.

Regresi data pool/panel bertujuan untuk melihat hubungan antar variabel dalam beberapa periode. Terdapat 3 macam model regresi data pool/panel yaitu Pooled Least Square (Common Effect Model), Fixed Effect Model, dan Random Effect Model.

5. Melakukan pengujian untuk memilih model yang terbaik.

Untuk memilih model yang tepat, ada beberapa uji yang perlu dilakukan. Pertama, menggunakan uji signifikansi fixed effect uji $\mathrm{F}$ atau Chow-test. Kedua, dengan menggunakan uji Hausman. Chow-test atau likelihood ratio test adalah pengujian untuk memilih apakah model yang digunakan adalah common effect atau fixed effect. Sedangkan uji Hausman adalah uji untuk memilih model fixed effect atau random effect.

6. Melakukan uji asumsi klasik.

Dalam melakukan metode regresi data panel, diperlukan uji asumsi klasik sebelum menjalankan model regresi. Adanya uji asumsi klasik ini bertujuan untuk memberikan kepastian bahwa persamaan regresi yang didapat memiliki ketepatan dalam estimasi, tidak bias, dan konsisten. Uji asumsi klasik yang dilakukan ada 4 jenis yaitu uji normalitas, uji multikolinearitas, uji autokorelasi, dan uji heteroskedastisitas.

7. Melakukan uji t (parsial).

Uji t dilakukan untuk mengetahui apakah variabel independen secara individu dapat mempengaruhi variabel dependen secara signifikan. Uji $t$ pada penelitian ini bertujuan untuk mengetahui seberapa pengaruh variabel independen $(\mathrm{X})$ terhadap variabel dependen $(\mathrm{Y})$ secara parsial.

8. Melakukan uji $F$ (simultan).

Uji F dilakukan untuk mengetahui apakah variabel-variabel independen secara bersama-sama 
dapat mempengaruhi secara signifikan variabel dependen. Hal ini dapat dilihat melalui nilai prob.F yang lebih kecil dari $5 \%$. Hal ini berarti variabel- variabel independen dapat mempengaruhi secara bersama-sama variabel dependen secara signifikan.

\section{ANALISIS DAN PEMBAHASAN}

Jumlah sampel yang digunakan pada penelitian ini sebanyak 31 perusahaan dari sektor industri barang konsumsi dengan pengamatan dari tahun 2013 hingga 2018. Dengan periode pengamatan selama 6 tahun, maka jumlah observasi pada penelitian ini sebanyak 186 observasi.

\section{Hasil Pengujian Data Panel}

1) Analisis Data Deskriptif

Hasil Uji statistik deskriptif dapat dilihat pada Tabel 1 yang menggambarkan nilai minimum, maksimum, rata-rata dan standard deviation setiap variabel.

Tabel 1. Statistik Deskriptif

\begin{tabular}{|l|ccccc|}
\hline Variabel & Obs & Mean & Std. Dev & Max & Min \\
\hline \hline FD1 & 186 & 0,122487 & 0,121678 & 0,455447 & 0 \\
FD2 & 186 & 0,072242 & 0,128062 & 0,947320 & 0 \\
FD3 & 186 & 0,194729 & 0,182864 & 1,047109 & 0 \\
BS & 186 & 5,897849 & 2,629417 & 16 & 2 \\
BC & 186 & 0,127539 & 0,124466 & 0,538462 & 0 \\
PROFIT & 186 & 0,139164 & 0,150293 & 0,625920 & $-0,211966$ \\
& & 10.581 .146$. & 19.248 .194$. & 96.537 .795$. & 298.090. \\
SIZE & 186 & $875.661,7$ & $011.112,6$ & 362.816 & 659.840 \\
\hline
\end{tabular}

2) Hasil Uji Chow-test

Sebelum melakukan uji regresi data panel, diperlukan uji Chow-test untuk melihat model yang paling tepat antara Pooled Least Square (Common Effect Model) dan Fixed Effect Model. Berdasarkan uji yang dilakukan, diperoleh hasil sebagai berikut:

Tabel 2. Hasil Uji Chow-test

Persamaan Tanpa Variabel Kontrol

\begin{tabular}{|c|c|c|c|}
\hline Persamaan & Effect Test & Prob. & Keterangan \\
\hline 3.6 & Cross-section $F$ & 0,0000 & Fixed Effect Model \\
\hline 3.7 & Cross-section $F$ & 0,0000 & Fixed Effect Model \\
\hline 3.8 & Cross-section $F$ & 0,0000 & Fixed Effect Model \\
\hline \multicolumn{4}{|c}{ Persamaan Dengan Variabel Kontrol }
\end{tabular}

\begin{tabular}{|c|c|c|c|}
\hline Persamaan & Effect Test & Prob. & Keterangan \\
\hline 3.9 & Cross-section $F$ & 0,0000 & Fixed Effect Model \\
\hline 3.10 & Cross-section $F$ & 0,0000 & Fixed Effect Model \\
\hline 3.11 & Cross-section $F$ & 0,0000 & Fixed Effect Model \\
\hline
\end{tabular}

3) Hasil Uji Hausman

Hasil uji Chow-test yang menolak hipotesis nol menunjukkan bahwa perlu dilakukan pengujian untuk memilih model yang terbaik melalui uji Hausman. Uji Hausman ini dilakukan untuk memilih model yang terbaik antara Fixed Effect Model dan Random Effect Model. Berikut ini adalah tabel hasil dari pengujian Correlated Random Effects - Hausman Test: 
Tabel 3. Hasil Uji Hausman

Persamaan Tanpa Variabel Kontrol

\begin{tabular}{|c|c|c|c|}
\hline Persamaan & Effect Test & Prob. & Keterangan \\
\hline 3.6 & Cross-section random & 0,2387 & Random Effect Model \\
\hline 3.7 & Cross-section random & 0,0328 & Fixed Effect Model \\
\hline 3.8 & Cross-section random & 0,2320 & Random Effect Model \\
\hline
\end{tabular}

Persamaan Dengan Variabel Kontrol

\begin{tabular}{|c|c|c|c|}
\hline Persamaan & Effect Test & Prob. & Keterangan \\
\hline 3.9 & Cross-section random & 0,3453 & Random Effect Model \\
\hline 3.10 & Cross-section random & 0,0429 & Fixed Effect Model \\
\hline 3.11 & Cross-section random & 0,1395 & Random Effect Model \\
\hline
\end{tabular}

4) Uji Asumsi Klasik

Regresi data panel merupakan regresi yang memiliki model perilaku yang rumit dengan data yang lebih informatif, lebih banyak variabilitas, lebih sedikit kolinearitas antar variabel, lebih banyak derajat kebebasan dan lebih banyak efisiensi (Gujarati, 2004). Dengan adanya keunggulan pada regresi data panel ini, maka pengujian asumsi klasik dalam model data panel tidak harus dilakukan.

5) Hasil Regresi Data Panel Tanpa Variabel Kontrol

Pengujian ini bertujuan untuk melihat pengaruh variabel independen terhadap variabel dependen yang digunakan pada penelitian ini. Uji regresi yang dilakukan yaitu menggunakan uji $\mathrm{t}$ (parsial) dan uji $\mathrm{F}$ (simultan). Hasil dari uji ini dapat dilihat dari tabel 4 berikut:

Tabel 4. Koefisien Regresi Tanpa Variabel Kontrol

\begin{tabular}{|l|c|c|c|c|c|c|}
\hline \multirow{2}{*}{ Variabel (FD1) } & \multicolumn{2}{|c|}{ Persamaan 3.6 (Fersamaan 3.7 (FD2) } & \multicolumn{2}{c|}{ Persamaan 3.8 (FD3) } \\
\cline { 2 - 7 } & Coefficient & Prob. & Coefficient & Prob. & Coefficient & Prob. \\
\hline \hline Intercept & 0,231290 & 0,0000 & $-0,091477$ & 0,2690 & 0,249649 & 0,0001 \\
BS & $-0,015511$ & $0,0113^{*}$ & 0,020052 & 0,1305 & $-0,012355$ & 0,1758 \\
BC & $-0,135832$ & $0,0355^{*}$ & 0,356404 & $0,0001^{*}$ & 0,140747 & 0,1438 \\
\hline Prob (F- & \multicolumn{7}{|c|}{0.012264} & \multicolumn{2}{|c|}{0,000000} & & 0,079544 \\
statistik) & 0,0126 & \\
\hline
\end{tabular}

6) Hasil Regresi Data Panel Dengan Variabel Kontrol

Setelah melihat pengaruh variabel independen secara parsial dan simultan terhadap variabel dependen, maka dilakukan pengujian regresi dengan variabel kontrol. Hal ini bertujuan untuk melihat pengaruh variabel independen terhadap masing-masing variabel dependen dengan profit dan size sebagai variabel kontrol. Hasil dari uji ini dapat dilihat dari tabel 5 berikut:

Tabel 5. Koefisien Regresi Dengan Variabel Kontrol

\begin{tabular}{|l|c|c|c|c|c|c|}
\hline \multirow{3}{*}{ Variabel } & \multicolumn{2}{|c|}{ Persamaan 3.9 (FD1) } & \multicolumn{2}{c|}{ Persamaan 3.10 (FD2) } & \multicolumn{2}{c|}{$\begin{array}{c}\text { Persamaan } 3.11 \\
\text { (FD3) }\end{array}$} \\
\cline { 2 - 7 } & & & & Coefficien & \\
& Coefficient & Prob. & Coefficient & Prob. & $t$ & Prob. \\
\hline \hline Intercept & 0,249723 & 0,0000 & $-0,091583$ & 0,2934 & 0,281686 & 0,0000 \\
BS & $-0,015817$ & $0,0134^{*}$ & 0,021874 & 0,1065 & $-0,012642$ & 0,1688 \\
BC & $-0,153136$ & $0,0186^{*}$ & 0,371615 & $0,0001^{*}$ & 0,106543 & 0,2677 \\
Profit & $-0,159996$ & 0,0661 & 0,043617 & 0,7665 & $-0,258299$ & $0,0428^{*}$ \\
Size & 7,4180253 & 0,4201 & $-1,7627624$ & 0,4733 & 9,4134815 & 0,4759 \\
\hline Prob (F- & \multicolumn{9}{|c|}{0,012661} & \multicolumn{2}{|c|}{0,000000} & \multicolumn{2}{|c|}{0,051111} \\
statistik)
\end{tabular}




\section{Pembahasan}

1) Pengaruh Board Size Terhadap Firm's Debt.

Dari hasil uji regresi yang dilakukan, pengujian tanpa variabel kontrol maupun dengan variabel kontrol tidak memberikan pengaruh terhadap hasil pengujian variabel board size. Hasil dari kedua regresi tersebut menunjukkan bahwa board size berpengaruh signifikan terhadap short term debt namun tidak berpengaruh signifikan terhadap long term debt dan total debt. Hal ini berarti dewan direksi pada perusahaan sektor industri barang konsumsi memfokuskan pendanaan mereka pada aset lancar sehingga hutang jangka pendek perusahaan lebih besar dari hutang jangka panjang.

2) Pengaruh Board Composition Terhadap Firm's Debt.

Hasil uji regresi menunjukkan bahwa pengujian dengan variabel kontrol tidak memberikan dampak terhadap hasil pengujian tanpa variabel kontrol. Dapat dilihat dari hasil uji regresi yang menyatakan bahwa board composition berpengaruh signifikan terhadap short term debt dan long term debt namun tidak berpengaruh signifikan terhadap total debt. Hal pengaruh signifikan pada short term debt dan long term debt ini sesuai dengan hasil (Wen, Rwegasira, \& Bilderbeek, 2002) yang menyatakan bahwa dengan adanya direktur independen, dewan direksi perusahaan cenderung untuk menekan hutang perusahaan karena mereka berfokus untuk meningkatkan harga saham perusahaan.

Board composition yang tidak berpengaruh signifikan terhadap total debt, hal ini sesuai dengan penelitian (Sheikh \& Wang, 2012) yang menyatakan bahwa direktur independen dapat membantu pemantauan kinerja dewan direksi lebih efektif dalam memaksimalkan kekayaan pemegang saham dengan adanya hutang yang tinggi. Namun, menurut (Robert, McNulty, \& Stiles, 2005), penempatan direktur independen tidak akan efektif karena direksi tersebut memiliki pengalaman dan pengetahuan yang minim akan perusahaan tersebut. Hal ini berarti direktur independen yang tidak dipekerjakan secara langsung oleh perusahaan akan memiliki informasi yang lebih sedikit mengenai internal perusahaan dibandingkan dewan direksi lainnya. Oleh karena itu, adanya direktur independen tidak menjamin penggunaan hutang yang tinggi ataupun rendah pada perusahaan.

3) Pengaruh Profitability dan Firm Size Terhadap Firm's Debt.

Berdasarkan hasil uji regresi yang dilakukan, variabel kontrol tidak memberikan pengaruh terhadap perubahan hasil pada variabel independen. Selain itu, hasil pengujian menunjukkan bahwa profitability tidak berpengaruh signifikan terhadap short term debt dan long term debt tetapi berpengaruh signifikan terhadap total debt. Sedangkan variabel firm size tidak berpengaruh signifikan terhadap short term debt, long term debt, dan total debt.

\section{KESIMPULAN}

Kemampuan perusahaan dalam membangun daya saing ditentukan oleh profit yang dimiliki perusahaan. Berdasarkan pembahasan sebelumnya maka dapat ditetapkan kesimpulan bahwa board size dan board composition yang merupakan komponen dari corporate governance secara parsial dan simultan berpengaruh signifikan terhadap short term debt. Board size yang merupakan komponen dari corporate governance tidak berpengaruh signifikan terhadap long term debt. Sedangkan board composition berpengaruh signifikan terhadap long term debt. Namun, hasil regresi kedua variabel ini secara bersama-sama berpengaruh signifikan terhadap long term debt. Board size dan board composition yang merupakan komponen dari corporate governance secara parsial dan simultan tidak berpengaruh signifikan terhadap total debt. Adanya penambahan 
variabel kontrol ke dalam persamaan regresi tidak mengubah hasil signifikansi dari masing-masing variabel independen ke variabel dependen. Pada penelitian ini terdapat beberapa keterbatasan. Oleh karena itu, berikut ini adalah keterbatasan dan saran bagi pihak-pihak yang ingin melanjutkan dengan variabel board size pada penelitian ini hanya berfokus pada jumlah dewan direksi dalam suatu perusahaan, tidak melihat pergantian orang dewan direksi pada board of directors. Pada penelitian selanjutnya dapat mempertimbangkan keberadaan pergantian orang pada dewan direksi, tidak hanya melihat jumlah dewan direksi pada suatu perusahaan. Pengembangan objek penelitian pada penelitian ini berfokus pada sektor industri barang konsumsi sehingga pada penelitian selanjutnya disarankan untuk menggunakan objek penelitian pada sektor lain agar dapat melihat perbedaan pengaruh dibandingkan penelitian ini. Penggunaan komponen corporate governance yang lain untuk melihat pengaruh signifikan terhadap firm's debt.

\section{DAFTAR PUSTAKA}

Abor, J. (2007). Corporate governance and financing decisions of Ghanaian listed firms. Corporate Governance, $7(1), 83-92$.

Adams, R. B., Hermalin, B. E., \& Weisbach, M. S. (2010). The role of boards of directors in corporate governance: A Conceptual Framework and Survey. Journal of Economic Literature 2010, 48 (1), 58-107.

Baysinger, B. D., \& Butler, H. N. (1985). Corporate governance and the board of directors: Performance effects of changes in board composition. Journal of Law, Economics, \& Organization, 1 (1), 101-124.

Bulan, F., \& Yuyetta, E. N. (2014). Pengaruh corporate governance terhadap capital structure. Diponegoro Journal of Accounting, 3 (11), 1-12.

Clarke, T. and Gholamshahi, S. (2016). Corporate Governance and Inequality: The Impact of Financialization and Shareholder Value. Finance and Economy for Society: Integrating Sustainability (Critical Studies on Corporate Responsibility, Governance and Sustainability, 11, Emerald Group Publishing Limited, pp. 27-55

Gujarati, D. N. (2004). Basic econometrics: Fourth Edition. New York: Mc. Graw Hill Companies.

Jackling, B., \& Johl, S. (2009). Board structure and firm performance: Evidence from India's top companies. Corporate Governance: An International Review, 17, 492-505.

KNKG. (2006). Pedoman umum good corporate governance Indonesia. Retrieved from ecgi.ppglobal: https://ecgi.global/sites/default/files//codes/documents/indonesia_cg_2006_id.pdf

Kurniati, S. (2019). Stock returns and financial performance as mediation variables in the influence of good corporate governance on corporate value. Corporate Governance, 19 (6), 1289-1309

Kusi, B.A., Gyeke-Dako, A., Agbloyor, E.K. and Darku, A.B. (2018). Does corporate governance structures promote shareholders or stakeholders value maximization? Evidence from African banks. Corporate Governance, 18(2), 270-288

Malelak, M. I. (2017). Manajemen Keuangan Lanjutan. Surabaya: Universitas Kristen Petra.

Munawir, S. (2004). Analisis Laporan Keuangan (4 ed.). Yogyakarta: Liberty.

Ogier, Rugman, J., \& Spicer, L. (2013). The real cost of capital. Great Britain: Pearson.

Robert, J., McNulty, T., \& Stiles, P. (2005). Beyond Agency Conceptions of the Work of the Non-Executive Director: Creating Accountability in the Boardroom. British Journal of Management, 16, 5-26.

Sheikh, N. A., \& Wang, Z. (2012). Effects of corporate governance on capital structure: empirical evidence from Pakistan. Corporate Governance: The international journal of business in society, 12 (5), 629-641.

Wen, Y., Rwegasira, K., \& Bilderbeek, J. (2002). Corporate governance and capital structure decisions of Chinese listed firms. Corporate Governance An International Review, 10 (2), 75-83. 